\title{
The Impact of The Coronavirus Disease 2019 Outbreak on The Quality of Life of Patients with Epilepsy
}

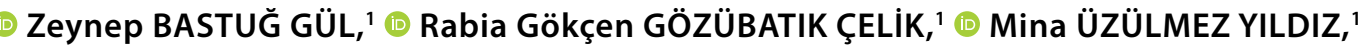 \\ (1) Sena AKSOY, ${ }^{1}$ (1) Serap Ruken TEKER, ${ }^{1}$ (1) Başak TÜZÜN MUTLUER, ${ }^{2}$ () Figen VARLIBAŞ, ${ }^{3}$

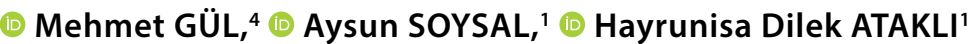

'Department of Neurology, University of Health Sciences, Bakirkoy Prof. Dr. Mazhar Osman Training and Research Hospital For Psychiatric, Neurologic and Neurosurgical Diseases, İstanbul, Turkey

${ }^{2}$ Department of Psychiatry, University of Health Sciences, Bakirkoy Prof. Dr. Mazhar Osman Training and Research Hospital for Psychiatric, Neurologic and Neurosurgical Diseases, İstanbul, Turkey

${ }^{3}$ Department of Neurology, University of Health Sciences, Istanbul, Turkey

${ }^{4}$ Department of Cardiology, University of Health Sciences, Istanbul Mehmet Akif Ersoy Thoracic and Cardiovascular Surgery Training and Research Hospital, Istanbul, Turkey

\begin{abstract}
Objectives: We aimed to investigate the effects of the coronavirus disease 2019 (COVID-19) outbreak on the quality of life (QOL) of patients with epilepsy.

Methods: A total of 104 epilepsy patients admitted to our hospital during October and November of 2019 were evaluated for their QOL using the QOL in Epilepsy-31 questionnaire. These assessments were repeated in July 2020 and August 2020 to evaluate the impact of the epidemic on the QOL of epilepsy patients in the same group. The data of the patients were analyzed in SPSS.

Results: During the pandemic period, overall score values decreased significantly compared to the pre-pandemic period ( $p=0.049)$. Although most of the subscores worsened with the pandemic, the most significant deterioration was observed in emotional well-being ( $p=0.021)$. There were six patients $(5.8 \%)$ whose seizure frequency increased during the pandemic period. In the multivariate analysis, the only parameter that predicted an increase in seizure frequency during COVID-19 was the overall score. Overall score had a positive correlation with educational level. Disease duration, age, marital status, and number of drugs used were found to be negatively correlated with the overall score of the patients. Conclusion: The COVID-19 epidemic causes a significant deterioration in QOL in patients with epilepsy. During epidemics such as COVID-19, clinicians should consider psychosocial factors. In patients with epilepsy, measures should be taken not only to control seizures but also to prevent deterioration in mental health and QOL.
\end{abstract}

Keywords: Coronavirus disease 2019; epilepsy; quality of life.

Cite this article as: Bastuğ Gül Z, Gözübatık Çelik RG, Üzülmez Yıldız M, Aksoy S, Teker SR, Tüzün Mutluer B, et al. The Impact of The Coronavirus Disease 2019 Outbreak on The Quality of Life of Patients with Epilepsy. Epilepsi 2021;27:78-84.

\section{Introduction}

In December 2019, the outbreak of coronavirus disease 2019 (COVID-19), identified as severe acute respiratory syn-

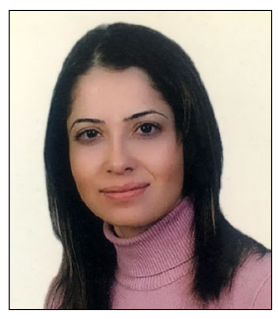

Corresponding author Zeynep BASTUĞ GÜL, M.D. e-mail drzeynep34@hotmail.com

Received 18.02.2021

Accepted 14.04.2021

Online date 21.04.2021

Content of this journal is licensed under a Creative Commons Attribution-NonCommercial 4.0 International License.

Zeynep BASTUĞ GÜL, M.D. drome coronavirus 2, was detected in Wuhan, China. This newly described viral disease was characterized by rapid human-to-human transmission with atypical pneumonia. With the World Health Organization (WHO) declaring COVID-19 a pandemic in March 2020, it quickly became a global health emergency. ${ }^{[1,2]}$

Public health emergencies can affect the health, safety, and well-being of both individuals and communities. These emergencies can cause a range of emotional reactions (such as distress or psychiatric conditions), unhealthy behavior, and non-compliance with public health directives in the general population. ${ }^{[3,4]}$ Patients with epilepsy and other chronic diseases are particularly likely to be affected by the 


\section{Koronavirüs Hastalığı 2019 Salgınının Epilepsi Hastalarında Yaşam Kalitesine Etkileri}

\section{$\ddot{0} z$}

Amaç: Koronavirüs hastalığı 2019 (COVID-19) salgınının epilepsi hastalarında yaşam kalitesi (QOL) üzerindeki etkilerini araştırmayı amaçladık. Gereç ve Yöntem: 2019 Ekim ve Kasım aylarında hastanemize başvuran toplam 104 epilepsi hastasının yaşam kalitesi epilepside yaşam kalitesi-31 (QOLIE-31) anketi ile değerlendirildi. Bu değerlendirmeler, salgının epilepsi hastalarının yaşam kalitesi üzerindeki etkisini değerlendirmek için Temmuz 2020 ve Ağustos 2020'de aynı hasta grubunda tekrarlandı. Hastaların verileri SPSS de analiz edildi.

Bulgular: Pandemi döneminde genel skor (overall scor) değerleri pandemi öncesi döneme göre anlamlı olarak azaldı ( $p=0.049$ ). Alt skorların çoğu pandemi ile kötüleşmesine rağmen, en önemli bozulma duygusal iyilikte gözlendi ( $p=0.021$ ). Pandemi döneminde nöbet sıklığı artan 6 hasta (\%5.8) vardı. Çok değişkenli analizde, COVID-19 sırasında nöbet sıklığında bir artışı öngören tek parametre genel skordu. Genel skor, eğitim seviyesi ile pozitif korelasyona sahipti. Hastalık süresi, yaş, medeni durum ve kullanılan ilaç sayısı ile hastaların genel skoru arasında negatif korelasyon olduğu görüldü.

Sonuç: COVID-19 salgını, epilepsili hastalarda yaşam kalitesi üzerinde önemli bir bozulmaya neden olmaktadır. COVID-19 gibi salgın hastalıklar sırasında klinisyenler psikososyal faktörleri dikkate almalıdır. Epilepsi hastalarında sadece nöbetleri kontrol altına almak için değil aynı zamanda ruh sağlığı ve yaşam kalitesinde bozulmayı önlemek için önlemler alınmalıdır.

Anahtar sözcükler: COVID-19; epilepsi; yaşam kalitesi.

COVID-19 pandemic, and there is still insufficient information on this subject.

Epilepsy is a common chronic neurological disorder that has many adverse effects on people's lives.[5] Patients with epilepsy may experience stigma, a lack of understanding from others, and social isolation, and as a result, they are at high risk for a poor quality of life (QOL). The WHO defines QOL as "an individual's perception of his/her position in life in the context of their culture and value systems and in relation to their goals, expectations, standards, and concerns."[6]

The relationship between epilepsy and QOL is an increasingly interesting topic. Studies have concluded that the QOL of patients with epilepsy is low and, in particular, that the frequency of seizures, age of onset, and side effects of antiepileptic drugs may be associated with this decline in QOL. It is known that patients with epilepsy are less able to work that their marriage rates are low and that their QOL is low, so they experience more social isolation than other adults. It is recommended that clinicians pay attention to all aspects of the health status of individuals with epilepsy, including mental health and QOL. ${ }^{[7,8]}$ In this way, we will be more successful in combating the disease by improving the QOL of patients and minimizing the factors that trigger the disease.

The QOL in epilepsy-31 inventory (QOLIE-31), which has been validated in our country, was used to measure the QOL of patients with epilepsy.

In this study, patients with epilepsy who were evaluated with the QOLIE-31 before the COVID-19 pandemic were re-evaluated during the pandemic period to examine the effects of the pandemic on their QOL. Our study presents preliminary data on the effect of the COVID-19 pandemic on the QOL of patients with epilepsy.

\section{Materials and Methods}

The QOLIE-31 inventory was used to evaluate the QOL of 104 patients with epilepsy in October and November 2019. With the declaration of COVID-19 as a pandemic by the WHO in March 2020, the assessments were re-evaluated in July and August 2020 to measure the impact of COVID-19 on the QOL of patients with epilepsy. This survey work was conducted face-to-face with all patients with epilepsy included in the study before and during the pandemic. Our study was carried out in a neurology sub-branch outpatient clinic where only epilepsy patients were specifically followed. Our study was conducted in Istanbul, Turkey, when the number of patients in the community was low during the first peak of COVID-19.

The validity and safety of the QOLIE-31 have been proven in our country. ${ }^{[9]}$ Through the QOLIE-31 scales, problems related solely to epilepsy are asked about. The inventory consists of 31 items. It also includes subscales, which appeared to be the most important aspect of the inventory based on reports by patients with epilepsy. The questionnaire comprises seven different categories: seizure anxiety (five items), overall QOL (two items), emotional well-being (five items), energy/fatigue (four items), cognitive function (six items), medication effects (three items), and social function (five items). In addition, there is a single item covering overall health (item 31). The inventory is scored on a scale from 0 to 100 . High scores reflect a high QOL. The QOLIE-31 overall score is calculated by taking the average of 30 items from 1 to 30 with a special formula. ${ }^{[10]}$ 
Demographic data on the patients such as gender, age, marital status, habits, and education level were obtained. In addition, information such as the age of onset of epilepsy, the duration of the disease, the type of seizure experienced, the frequency of seizures, the increase in the frequency of seizures during the COVID-19 period, and the number of drugs taken was recorded by the researchers in the SPSS format. Written consent from volunteer patients who met the inclusion criteria was obtained. Interviews with patients were conducted in the interictal period.

Patients in the 18-65 age group with focal or generalized epileptic seizures who were diagnosed with definite epilepsy were included in the study. The exclusion criteria were (1) patients using any psychiatric medication; (2) patients whose seizures were due to causes such as acute infection, metabolic disorder, or tumor mass; (3) among the patients who participated in the pre-pandemic questionnaire, those who could not be followed during the pandemic period; and (4) those with COVID-19 disease. Approval for the study was obtained from the local ethics committee (2020/319) and the ministry of health (2020-0619T20_26_24).

Our study enrolled 152 patients before the COVID-19 pandemic to evaluate the QOL of patients with epilepsy. With the onset of the COVID-19 pandemic, these patients were recalled with the idea that COVID-19 could have effects on the QOL of patients with epilepsy. During the COVID-19 period, 28 patients were not followed up on, and 20 patients were excluded from the study; a total of 48 patients were excluded from the study. Complete data for the QOL of 104 patients were obtained, and there were no patients with COVID-19 in the study.

Statistical Analysis- Statistical analysis was performed using SPSS 17.0 for Windows (SPSS, Inc.). A Pp $<0.05$ was considered statistically significant. Continuous variables (such as mean \pm standard deviation) and categorical variables (such as percentages) were expressed. Paired sample testing was used to compare the QOLIE-31 results of patients with epilepsy before and during COVID-19. Quantitative variables were compared using an independent t-test between the two groups and an analysis of variance between more than two groups. Spearman correlation analysis was used to evaluate the relationship of various parameters with each other. For multivariate analysis, $p<0.1$ values in univariate analysis were taken as possible factors and further logistic regression analysis was performed to identify independent predictors of increased seizure frequency in the COVID-19 period.

\section{Results}

A total of 104 patients with epilepsy who met the inclusion criteria and were followed up on during the COVID-19 period were included in the study. The patients consisted 46 males and 58 females between the ages of 18-65. The basic demographic and clinical characteristics of the patients included in the study are detailed in Table 1.

Table 2 shows the QOLIE-31 overall score and subgroup values before and during the COVID-19 period. During the pandemic period, the overall score values decreased significantly compared to the pre-pandemic period $(p=0.049)$.

Table 1. Demographic characteristics of patients with epilepsy $(n=104)$

\begin{tabular}{|c|c|}
\hline Age, mean (min-max) & $32(18-65)$ \\
\hline Female, n (\%) & $58(55.8)$ \\
\hline Male, n (\%) & $46(44.2)$ \\
\hline Smoker, n (\%) & $19(18)$ \\
\hline Using alcohol, n (\%) & $6(5.8)$ \\
\hline Single drug, $\mathrm{n}(\%)$ & $60(57.7)$ \\
\hline Dual drug, n (\%) & $33(31.7)$ \\
\hline Multidrug, n (\%) & $11(10.6)$ \\
\hline \multicolumn{2}{|l|}{ Education level, n (\%) } \\
\hline Primary school & $24(23.1)$ \\
\hline Middle school & $16(15.4)$ \\
\hline High school & $33(31.7)$ \\
\hline University & $31(29.8)$ \\
\hline \multicolumn{2}{|l|}{ Marital statuse, n (\%) } \\
\hline Singl & $46(44.2)$ \\
\hline The married & $56(53.8)$ \\
\hline Divorced & $2(1.9)$ \\
\hline Disease onset age, years, n (\%) & $17.01 \pm 9.05$ \\
\hline Duration of illness, years, n (\%) & $16.01 \pm 10.1$ \\
\hline Seizure type, focal, n (\%) & $32(30.8)$ \\
\hline Generalized, n (\%) & $72(69.2)$ \\
\hline \multicolumn{2}{|l|}{ Seizure frequencye, $\mathrm{n}(\%)$} \\
\hline More than 1 month & $5(4.8)$ \\
\hline 1 month-1 year & $37(35.6)$ \\
\hline Less than 1 year & $62(59.6)$ \\
\hline \multicolumn{2}{|l|}{ EEG findinge, $\mathrm{n}(\%)$} \\
\hline Normal & $38(36.5)$ \\
\hline Generalize & $42(40.4)$ \\
\hline Focal & $24(23.1)$ \\
\hline $\begin{array}{l}\text { The number of patients whose seizure } \\
\text { frequency increased during the } \\
\text { pandemic period, } n(\%)\end{array}$ & $6(5.8)$ \\
\hline $\begin{array}{l}\text { Number of patients experiencing } \\
\text { difficulties in drug supply during } \\
\text { the pandemic period, } \mathrm{n}(\%)\end{array}$ & $2(1.9)$ \\
\hline
\end{tabular}


Table 2. The quality of life in epilepsy inventory overall score and subgroup values before and during COVID-19 period

\begin{tabular}{lcccc}
\hline & Number sayısI & Before COVID-19 & During COVID-19 & p-value \\
\hline Seizure worry & 5 & $56.18 \pm 30.72$ & $54.52 \pm 31.77$ & 0.42 \\
Overall quality of life & 2 & $58.63 \pm 20.82$ & $56.04 \pm 20.49$ & 0.19 \\
Emotional well-being & 5 & $58.97 \pm 17.29$ & $55.16 \pm 18.22$ & 0.021 \\
Energy/fatigue & 4 & $51.09 \pm 20.12$ & $51.22 \pm 22.13$ & 0.94 \\
Cognitive function & 6 & $55.11 \pm 21.54$ & $51.60 \pm 19.82$ & 0.060 \\
Medication effects & 3 & $56.07 \pm 29.52$ & $54.76 \pm 29.51$ & 0.63 \\
Social function & 5 & $69.60 \pm 25.60$ & $67.59 \pm 25.21$ & 0.31 \\
Last item (31.) & 1 & $64.53 \pm 22.14$ & $63.39 \pm 21.96$ & 0.55 \\
Overall score & $30(1$ to 30) & $58.83 \pm 16.59$ & $56.38 \pm 17.10$ & 0.049 \\
\hline
\end{tabular}

Table 3. Distribution of the overall score value for quality of life by education level

\begin{tabular}{lccc}
\hline Education level & Before COVID-19 & P-value between primary school and other levels & $\mathrm{p}$-value \\
\hline Primary school & $46.02 \pm 15.6(14.16-77.68)$ & & $<0.001$ \\
Middle school & $59.42 \pm 16.5(27.08-85.68)$ & $\mathrm{p}=0.055$ & \\
High school & $61.04 \pm 15.3(23.40-91.78)$ & $\mathrm{p}=0.003$ & \\
University & $64.95 \pm 16.21(31.27-92.89)$ & $\mathrm{p}=0.001<$ & \\
\hline Education level & During COVID-19 & & $<0.001$ \\
\hline Primary school & $41.06 \pm 15.6(13.40-67.27)$ & $\mathrm{p}=0.002$ & \\
Middle school & $59.61 \pm 17.5(33.0-79.94)$ & $\mathrm{p}=0.001<$ & \\
High school & $60.51 \pm 12.2(32.0-82.40)$ & $\mathrm{p}=0.001<$ & \\
University & $62.99 \pm 17.1(31.96-92.89)$ & & \\
\hline
\end{tabular}

Mean values (standard deviation) and (min-max), respectively.

Table 4. Correlation analysis of COVID-19 during overall score value and other parameters

\begin{tabular}{lcc}
\hline & \multicolumn{2}{c}{ Overall score } \\
\cline { 2 - 3 } & $\mathrm{r}$ & $\mathrm{p}$-value \\
\hline Marital status & -0.189 & 0.065 \\
Educational level & 0.388 & $0.001<$ \\
Duration of illness & -0.257 & 0.011 \\
The number of drugs used & -0.264 & 0.009 \\
Age (years) & -0.271 & 0.007 \\
\hline
\end{tabular}

When the QOL subscores before and during COVID-19 were compared, the biggest difference was observed in the group of emotional well-being subscores $(p=0.021)$. Although most of the other QOL subscores decreased during the COVID-19 period, they did not do so to a statistically significant degree (Table 2).

Other QOL variables were investigated. It was observed that the lower the education level, the lower the QOL. Primary school graduates, in particular, had slightly lower QOL scores than other education levels $(p<0.001)$, and this characteristic was similar before and during the pandemic period (Table 3).

Correlation analysis of COVID-19 in terms of overall score and other parameters is shown in Table 4. Disease duration, age, marital status, and the number of drugs used were found to be negatively correlated with the overall score of the patients. The overall score positively correlated with educational level.

Univariate and multivariate logistic regression analysis determined the independent parameters affecting the frequency of seizures in the COVID-19 period, as shown in Table 5. During the COVID-19 pandemic, the number of drugs used, the frequency of seizures, and the overall score were evaluated by univariate analysis. In the multivariate analysis, only the overall score predicted an increase in seizure frequency during COVID-19. Findings before and during the COVID-19 period in terms of EEG findings (normal/abnormal), smoking or alcohol use, seizure type (focal/general- 
Table 5. Univariate and multivariate analyses for independent predictors of increase in seizure frequency in COVID-19 period

\begin{tabular}{lccccccc}
\hline & \multicolumn{3}{c}{ Univariate } & & \multicolumn{3}{c}{ Multivariate } \\
\cline { 2 - 3 } & OR & $\mathrm{Cl}$ & $\mathrm{p}$-value & & $\mathrm{OR}$ & $\mathrm{Cl}$ & $\mathrm{p}$-value \\
\hline COVID-19 during overall score & 0.934 & $0.883-0.988$ & 0.017 & & 0.940 & $0.884-0.999$ & 0.048 \\
The number of drugs used & 3.449 & $1.125-10.574$ & 0.030 & & 2.301 & $0.471-11.226$ & 0.303 \\
Seizure frequency & 2.939 & $0.809-10.679$ & 0.10 & & 1.114 & $0.172-76.24$ & 0.889 \\
\hline
\end{tabular}

OR: Odds ratio; Cl: Confidence interval.

ized) of the patients did not have a significant effect on QOL scores $(p>0.05)$.

\section{Discussion}

In this survey study, we evaluated the impact of the COVID-19 outbreak on the QOL of patients with epilepsy. During the pandemic period, overall score values decreased significantly compared to the pre-pandemic period $(p=0.049)$. Although most of the subscores worsened with the pandemic, the most significant deterioration was observed in emotional well-being subscores $(p=0.021)$. There were $6(5.8 \%)$ patients who experienced increased seizure frequency during the pandemic period. In the multivariate analysis, the only parameter that predicted an increase in seizure frequency during COVID-19 was the overall score. Since there are no other data on this subject in the literature to the best of our knowledge, our study includes the first information on this subject.

For centuries, new types of viruses such as influenza have led to widespread epidemics in societies. Pandemics can have many negative social and psychological effects on societies and individuals. Data published after the announcement of COVID-19 in China show that negative emotions (e.g., anxiety, depression, and anger) and susceptibility to social risks have increased. Positive emotion scores and life satisfaction values have decreased. While people were more concerned with their health and family, they were less concerned about fun and friends. ${ }^{[3,1]}$ Epilepsy is characterized by recurring seizures but causes serious problems in an individual's emotional, psychological, intellectual, and social functions. While all chronic diseases affect the $\mathrm{QOL}$ of a person, the effect in people with epilepsy may be more pronounced. Depending on the severity of the epileptic seizures, people have to limit their life in different places. Studies have shown that seizures and psychological causes can have a detrimental effect on epileptic patients' QOL.

COVID-19 spreads rapidly and can be seen in people of all ages. It has been established that the virus not only affects the lungs and heart but also has multisystemic effects, including to the central nervous system. The coronavirus pandemic impacts epilepsy patients as well as society at large. ${ }^{[12,13]}$ Current data do not indicate that COVID-19 causes or worsens epileptic seizures in patients with existing epilepsy. Secondary seizures attributable to infection have been caused. Furthermore, it is understood that neither the existence of the disease nor antiepileptic drugs used to raise the risk of COVID-19 or i responsible for a poor prognosis of COVID-19. ${ }^{[14]}$

Studies show the effectiveness of a structured education program in improving drug compliance and $\mathrm{QOL}$ in groups of patients with epilepsy with a low level of education. ${ }^{[15]}$ We found that the lower the education level, the lower the QOL; primary school graduates in particular had slightly lower QOL scores than those with other education levels $(p<0.001)$. Therefore, it is important to educate and inform patients with low education levels. A lack of awareness about epilepsy and inadequate professional support can cause physical and psychosocial issues in patients. Educational services and the provision of comprehensive treatment according to patient needs can have a positive impact on patient satisfaction, as well as on QOL. In the management of epilepsy, clinicians specializing in epilepsy plays a vital role in raising awareness and providing resources for patients and their families. ${ }^{[16,17]}$

Overall score was found to be negatively correlated with disease duration, age, marital status, and the amount of medication used, and all of the correlations except marital status were statistically significant. Overall score is significantly positively correlated with education level. Another factor affecting QOL in epilepsy patients is the amount of medication used by patients daily. In this context, it has been reported in various publications that the QOL of particularly resistant patients with epilepsy is negatively affected by both the high number of drugs and the inability to control their seizures. ${ }^{[18,19]}$ In our study, we showed that QOL decreased as the number of drugs increased during the pandemic period. 
In one study, it was found that healthcare professionals experienced psychological problems due to COVID-19. ${ }^{[20]}$ In a psychological stress study in which 252 epilepsy patients and 252 healthy controls participated through an online form, it was observed that epilepsy patients scored higher than the normal population during the COVID period. ${ }^{[21]}$ In our study, it was observed that the emotional well-being scores of patients with epilepsy during the pandemic period decreased significantly compared to the pre-pandemic period. In another study examining the QOL of 160 patients with epilepsy, it was found that gender, epilepsy type, and epilepsy duration did not significantly affect QOL. In a study, it was reported that seizure frequency and psychosocial factors were associated with QOL scores. ${ }^{[22]}$ In our study, QOL was found to be related to the duration of the disease, the amount of drugs used, education level, and age.

Stress is an independent trigger of seizures in patients with epilepsy, who described themselves as less reliable, less mature, less successful, more unstable, less compliant, less valuable, and less able to adapt than people without epilepsy. Furthermore, epilepsy-related stigma was found to be associated with low self-perception, high anxiety levels, and depression. If people with epilepsy have symptoms of stress and depression, they should be treated accordingly. However, decreases in QOL can be prevented by education. ${ }^{[23-25]}$ In a previous study that we conducted in our center, we evaluated drug compliance and stigmatization in patients with epilepsy. ${ }^{[1]}$ In that previous study, the COVID-19 outbreak did not adversely affect drug compliance and stigmatization, and in this study, we observed a deterioration in QOL. In another study we did, the COVID-19 outbreak caused an increase in depression tendency and a negative impact on sexual function in epilepsy patients. ${ }^{[26]}$

Study Limitations- The first limitation is that it is a single-center study and the number of patients is limited. Second, more valuable information would have been obtained if the study had been designed to compare patients with epilepsy with healthy controls. Depression and anxiety were not evaluated in our study.

Conclusion- In our study, we found that overall scores assessing QOL in epilepsy patients decreased during the pandemic and that the most statistically significant decrease was in emotional well-being subscores. In pandemics such as COVID-19, clinicians must consider psychosocial factors. Measures should be taken not only to control seizures but also to prevent deterioration in mental health and $\mathrm{QOL}$ in patients with epilepsy.
Informed Consent- Written informed consent was obtained from patients who participated in this study.

Ethics Committee Approval- This study approved by the Bakirkoy Dr. Sadi Konuk Training and Research Hospital Ethics Committee (Date: 06.07.2020, Decision No: 2020/319).

Peer-review- Externally peer-reviewed.

Authorship Contributions- Concept: Z.B.G., R.G.G.Ç., A.S.; Design: Z.B.G., R.G.G.Ç., A.S.; Data collection \&/or processing: M.Ü.Y., S.A.; Analysis and/or interpretation: M.G., S.R.T., B.T.M.; Literature search: F.V., M.G.; Writing: Z.B.G.; Critical review: H.D.A., Z.B.G.

Conflict of interest-The authors declare that they have no conflict of interest.

Financial Disclosure: The authors declared that this study has received no financial support.

\section{References}

1. Gul ZB, Atakli HD. Effect of the COVID-19 pandemic on drug compliance and stigmatization in patients with epilepsy. Epilepsy Behav 2021;114:107610. [CrossRef]

2. Cabona C, Deleo F, Marinelli L, Audenino D, Arnaldi D, Rossi F, et al. Epilepsy course during COVID-19 pandemic in three Italian epilepsy centers. Epilepsy Behav 2020;112:107375. [CrossRef]

3. Akin L, Gozel MG. Understanding dynamics of pandemics. Turk J Med Sci 2020;50(Supple 1):515-9. [CrossRef]

4. Pfefferbaum B, North CS. Mental health and the Covid-19 pandemic. N Engl J Med 2020;383(6):510-2. [CrossRef]

5. Gholami A, Salarilak S, Lotfabadi P, Kiani F, Rajabi A, Mansori K, et al. Quality of life in epileptic patients compared with healthy people. Med J Islam Repub Iran 2016;30:388.

6. WHO Quality of Life Assessment Group. What is quality of life? World Health Organization Quality of Life Assessment Group. World Health Forum 1996;17(4):354-6.

7. French JA, Brodie MJ, Caraballo R, Devinsky O, Ding D, Jehi L, et al. Keeping people with epilepsy safe during the COVID-19 pandemic. Neurology 2020;94(24):1032-7. [CrossRef]

8. Healy SA, Fantaneanu TA, Whiting S. The importance of mental health in improving quality of life in transition-aged patients with epilepsy. Epilepsy Behav 2020;112:107324. [CrossRef]

9. Mollaoğlu M, Durna Z, Bolayir E. Validity and reliability of the quality of life in epilepsy inventory (QOLIE-31) for Turkey. Noro Psikiyatr Ars 2015;52(3):289-95. [CrossRef]

10. Vickrey BG, Perrine K, Hays RD, Hermann BP, Cramer JA, Meador KJ. Quality of Life in Epilepsy QOLIE-31 (Version 1.0): Scoring Manual and Patient Inventory. Santa Monica; CA: RAND; 1993.

11. Li S, Wang Y, Xue J, Zhao N, Tingshao Z. The Impact of COVID-19 epidemic declaration on psychological consequences: $A$ study on active weibo users. Int J Environ Res Public Health 2020;17(6):2032. [CrossRef]

12. Nath A. Neurologic complications of coronavirus infections. 
Neurology 2020;94(19):809-10. [CrossRef]

13. Acar T, Demirel EA, Afşar N, Akcalı A, Demir GA, Alagoz AN, et al. Norolojik bakış acısından COVID-19. Turk J Neurol 2020;26(2):56-106.

14. Elmalı AD, Bebek N, Yildirim I, Ayat S, Altındag E, Aslan K, et al. COVID-19 and epilepsy: Its effects on seizures, treatment and social life. Epilepsi 2020;26(2):49-58.

15. Dash D, Sebastian TM, Aggarwal M, Tripathi M. Impact of health education on drug adherence and self-care in people with epilepsy with low education. Epilepsy Behav 2015;44:213-7.

16. Helde G, Bovim G, Brathen G, Brodtkorb E. A structured, nurseled intervention program improves quality of life in patients with epilepsy: A randomized, controlled trial. Epilepsy Behav 2005;7(3):451-7. [CrossRef]

17. Karaca A, Durna Z. Psychosocial support in epilepsy patient. GUSBD 2018;7(1):218-25.

18. Acaroglu G,Yilmaz E. Effects of drug compliance on quality of life in patients with epilepsy. Epilepsi 2016;22(1):17-25. [CrossRef]

19. Aggarwal HK, Jain D, Bishnoi A. Quality of life in patients with drug resistant epilepsy. Turk J Neurol 2019;25(3):159-63. [CrossRef]

20. Nathiya D, Suman S, Singh P, Raj P, Tomar BS. Mental health outcome and professional quality of life among healthcare worker during COVID-19 pandemic: A (FRONTLINE-COVID) survey. Ann Med Psychol (Paris) 2020;13(4):196-202. [CrossRef]

21. Hao X, Zhou D, Li Z, Zeng G, Hao N, Li E, et al. Severe psychological distress among patients with epilepsy during the COVID-19 outbreak in southwest China. Epilepsia 2020;61(6):1166-73. [CrossRef]

22. Alsaadi T, Kassie S, El Hammasi K, Shahrour MT, Shakra M, Turkawib $L$, et al. Potential factors impacting health-related quality of life among patients with epilepsy: Results from the United Arab Emirates. Seizure 2017;53:13-7. [CrossRef]

23. Huang S, Wu C, Jia Y, Li G, Zhu Z, Lu K, et al. COVID-19 outbreak: The impact of stress on seizures in patients with epilepsy. Epilepsia 2020;61(9):1884-93. [CrossRef]

24. Jacoby A. Stigma, epilepsy, and quality of life. Epilepsy Behav 2002;3(6S2):10-20. [CrossRef]

25. Westbrook LE, Bauman LJ, Hýnnar S. Applying stigma theory to epilepsy: A test of a conceptual model. J Pediatr Psychol 1992;17(5):633-49. [CrossRef]

26. Gul ZB. Depression and sexual functions in epilepsy patients: Comparison before and during the COVID-19 pandemic. Ann Med Psychol (Paris). 2021 Feb 16. doi: 10.1016/j. amp.2021.02.006. [Epub ahead of print] [CrossRef] 